\title{
Assessment of the anti-quorum sensing effect of Lactobacillus sp. metabolites on expression levels of QS-related genes in Pseudomonas aeruginosa PAO1
}

\section{Pseudomonas aeruginosa PA01'de QS ilișkili genlerin ekspresyon seviyeleri üzerine Lactobacillus sp. metabolitlerinin anti-quorum sensing etkilerinin belirlenmesi}

\section{Didem KART ${ }^{1}$, Suna Sibel GÜRPINAR ${ }^{2}$, Müjde ERYILMAZ ${ }^{2}$}

\section{ABSTRACT}

Objective: Pseudomonas aeruginosa is an important pathogen associated with nosocomial infections and its pathogenicity is mostly linked with the quorum sensing (QS) system. The aim of this study was to evaluate the anti-QS activity of the metabolites of vaginal Lactobacillus isolates and to investigate the effect of these metabolites on transcriptional regulation of QS related genes in $P$. aeruginosa PAO1.

Methods: In this study, 13 Lactobacillus isolates that were previously identified by 165 rRNA gene sequence analysis were used. Metabolites of these isolates were assessed for the anti-QS activity by using Chromobacterium violaceum CV12472. The influence of metabolites on the expression of QS related genes was also examined by reverse transcription-quantitative polymerase chain reaction (RT-qPCR).

Results: All tested metabolites exhibited anti-QS activity with the appearance of a non-pigmented zone of C. violaceum. All tested quorum sensing-related genes (lasl, lasR, rhlR and mvfR) in P. aeruginosa PAO1 showed significant down-regulation after treating with the metabolites.

\section{ÖZET}

Amaç: Pseudomonas aeruginosa hastane enfeksiyonları ile ilișkili önemli bir patojen olup patojenitesi çoğunlukla quorum sensing (QS) sistemi ile ilișkilidir. Bu çalıșmanın amacı, vajinal Lactobacillus izolatlarının metabolitlerinin anti-QS aktivitelerinin değerlendirilmesi ve metabolitlerin $P$. aeruginosa PAO1'in QS ilișkili genlerinin transkripsiyonel regülasyonu üzerindeki etkilerinin araștırılmasıdır.

Yöntem: Çalıșmamızda daha önce 16S rRNA gen dizi analizi ile tanımlanmıș olan 13 adet Lactobacillus izolatı kullanılmıștır. Bu izolatların metabolitlerinin, Chromobacterium violaceum CV12472 sușu kullanılarak anti-QS aktiviteleri değerlendirilmiștir. Metabolitlerin QS ile ilișkili genlerin ekspresyonları üzerindeki etkisi kantitatif revers transkriptaz polimeraz zincir reaksiyonu RT-qPZR ile araștırılmıștır.

Bulgular: Test edilen tüm metabolitler $C$. violaceum'un șeffaf zon bölgesi görünümü ile karakterize edilen anti-QS aktivite göstermișlerdir. Metabolitlerle temas sonrasinda $P$. aeruginosa PAO1'de, test edilen tüm quorum sensing ilișkili genler (lasl, lasR, rhlR ve $m v f R$ ) anlamlı bir down-regülasyon göstermișlerdir.

${ }^{1}$ Hacettepe University, Faculty of Pharmacy, Department of Pharmaceutical Microbiology, Ankara

${ }^{2}$ Ankara University, Faculty of Pharmacy, Department of Pharmaceutical Microbiology, Ankara

İletişim / Corresponding Author : Didem KART 
Conclusion: New anti-infection agents from natural resources with a different mode of action are necessary due to the increasing occurrence of antibacterial resistance. Our study highlights the possible usage of Lactobacillus metabolites as an anti-QS agent against $P$. aeruginosa biofilm cells in vitro.

Key Words: anti-quorum sensing activity, Lactobacillus sp., metabolites, RT-qPCR. Pseudomonas aeruginosa
Sonuç: Antibakteriyel direncin artması nedeniyle farklı etki mekanizmasına sahip doğal kaynaklardan köken alan, enfeksiyonlara karșı yeni ajanlar gerekmektedir. Çalıșmamız, in vitro Pseudomonas biyofilmlerinin kontrolünde Lactobacillus metabolitlerinin olası anti-QS ajanı olarak kullanılabileceklerini vurgulamaktadır.

Anahtar Kelimeler: anti-quorum sensing aktivitesi, Lactobacillus sp., metabolitler, RT-qPCR, Pseudomonas aeruginosa

\section{INTRODUCTION}

Pseudomonas aeruginosa is one of the significant opportunistic pathogens which causes numerous chronic infections such as severe burn infections, urinary tract infections, blood circulation and nosocomial infections (1). $P$. aeruginosa communicates and coordinates with other cells in a microbial population using small signaling molecules such as acyl-homoserine lactones (AHLs) known as quorum sensing (QS), contributing to its pathogenicity by regulating multiple virulence properties (2). QS system controls the expressions of various virulence genes depending on cell density and also triggers the biofilm formation which is one of the most important virulence factors of $P$. aeruginosa (3). P. aeruginosa has two QS systems known as lasR// and rhl//R, which use AHL signaling molecules. Lasl is necessary for the synthesis of $\mathrm{N}$ - (3-oxododecanoyl) -L-homoserine lactone (3-oxo-C12-HSL) and lasR is a transcriptional regulator of virulence genes $(4,5)$. Among $\mathrm{rhll} / \mathrm{rhlR}$ synthase proteins, rhll mediates the synthesis of the N-butyryl-homoserine lactone (c4-HSL) signaling molecule and RhIR is a transcriptional regulator (6). The synthesis of various virulence factors such as elastase, protease, exotoxin A, pyocyanin pigment production, rhamnolipids and biofilm formation which play an important role in cellular cytotoxicity and acute infections of $P$. aeruginosa are controlled by lasR/I and $r h l / R(7,8)$.

QS inhibitors (QSIs) do not inhibit the growth of the pathogenic microorganism but lead to suppression of pathogenicity by decreasing virulence properties (9). Unlike conventional antibiotics targeting the cellular metabolic processes of the microorganism, QSIs inhibit the communication between the biofilm cells without exerting selective pressure for the development of resistance (3). Hence, inhibitor agents blocking the QS system in bacteria are considered as the possible options to fight with the infections caused by $P$. aeruginosa. The existence of bacterial persistence in chronic infections and increases in reduced susceptibility profiles to antimicrobials indicate the necessity of further investigations on anti-QS agents, especially from natural sources (5).

Lactobacillus species are normal flora members of mucosal surfaces in humans and some metabolites of Lactobacillus spp. such as lactic acid, acetic acid, hydrogen peroxide, and bacteriocin have the preservative property $(10,11)$. In the literature, the anti-biofilm effects of Lactobacillus spp. against Staphylococcus aureus and $P$. aeruginosa resistant strains were reported and many researchers have 
focused on their use as alternative agents in the treatment of biofilm-associated infections (12-14).

The main objectives of this study were to investigate the anti-QS activity of the metabolites of vaginal Lactobacillus isolates and to evaluate the effect of these metabolites on the expression profile of QS-related genes in $P$. aeruginosa PAO1.

\section{MATERIAL and METHOD}

\section{Lactobacillus isolates}

In this study, metabolites of one $L$. helveticus, one $L$. fermantum, one $L$. jensenii, six L. gasseri, two $L$. vajinalis, and two $L$. crispatus vaginal isolates which were previously identified at the species-level by analyzing the $16 \mathrm{~S}$ rRNA gene sequence were used (11).

\section{Obtaining metabolites}

A total of 13 Lactobacillus isolates were grown on Rogosa Agar for 24-48 hours following the inoculation into tubes containing $5 \mathrm{~mL}$ of De Man-Rogosa Sharpe (MRS) Broth (pH 6.5) (Merck, Germany), under anaerobic conditions for 72 hours at $37^{\circ} \mathrm{C}$. After the incubation period, the cells were removed by centrifugation at $12000 \mathrm{~g}$, for $10 \mathrm{~min}$, at $4^{\circ} \mathrm{C}$. Cell-free supernatants (CFS) of the cells were filtered for the sterilization ( $0.45 \mu \mathrm{m}$ pore size) (Minisart, Germany) $(11,15)$.

\section{Biofilm formation}

P. aeruginosa PAO1 was incubated for 24 hours at $37^{\circ} \mathrm{C}$ in Brain Heart Infusion (BHI) Broth. After the incubation period, final inoculum suspensions containing $\sim 106 \mathrm{cfu} / \mathrm{ml}$ of P. aeruginosa were prepared in BHI. For each test condition, $100 \mu \mathrm{l}$ of the inoculum suspensions were added to the wells of 96-well microtiter plates following the incubation for 4 hours at $37{ }^{\circ} \mathrm{C}$. At the end of 4 hours, the wells were washed with phosphate buffer saline (PBS) three times in order to remove the non-adherent cells. After the washing step, the plates were incubated for an additional 20 hours to form mature biofilms (16).

Treating of the biofilm cells with the metabolites of Lactobacillus isolates

The metabolite of each isolate $(100 \mu \mathrm{l})$ was transferred into the wells containing mature $P$. aeruginosa biofilms and the plates were incubated for 24 hours at $37{ }^{\circ} \mathrm{C}$. After incubation time, the plates were vortexed for 5 minutes and then sonicated 3 times for 5 minutes. Biofilm cells were then transferred into a sterile tube and evaluated for anti-QS activity.

\section{Detection of anti-QS activity}

The agar well diffusion method was performed against reporter bacteria Chromobacterium violaceum ATCC 12472. One hundred microliters of the metabolites were loaded onto the wells ( $8 \mathrm{~mm}$ diameter) made on Luria Bertani Agar plates, pre-inoculated with C. violaceum. The plates were observed for the presence of zone of violacein inhibition after 24 hours of incubation at $30{ }^{\circ} \mathrm{C}$ (3). The appearance of clear zone of $C$. violaceum around the well loaded with the metabolites of Lactobacillus sp. isolates indicated the potential anti-QS activity.

\section{Gene expression analysis}

P. aeruginosa biofilms were grown and harvested and incubated with Lactobacillus sp. metabolites as described above. The mRNA expression changes of QS-related genes including $r h l R, r h l l, l a s R$, lasl and $m v f R$ in $P$. aeruginosa biofilms were assessed using quantitative polymerase chain reaction qPCR. Total RNA was extracted by RNA Isolation Kit according to the manufacturer's instructions (Roche Life Science). Total RNA was quantified in each sample using a NanoDrop spectrophotometer (BioDrop, Cambridge, UK). First-strand CDNA was synthesized by Evoscript Universal cDNA Master according to the manufacturer's instructions (Roche Life Science). To quantify cDNA, primers that correspond to $P$. aeruginosa genes were used (17). The sequences of the primers are presented 
in Table 1. Real-time PCR (LightCycler 96 Instrument) was carried out with the Faststart Essential DNA Green Master (Roche Life Science) in 96-well plates in Roche LightCycler 96 Instrument (Roche, USA). Five $\mu \mathrm{l}$ of $1: 2$ diluted cDNA samples and $20 \mu \mathrm{l}$ of master mix (containing the primers) were added to each well. The parameters for real-time PCR reactions included a single cycle of $95^{\circ} \mathrm{C}$ for 5 min followed by 40 cycles of $95^{\circ} \mathrm{C}$ for $15 \mathrm{~s}$ and $60^{\circ} \mathrm{C}$ for $1 \mathrm{~min}$. The formula, fold change $=2-\Delta \Delta \mathrm{Ct}$, was used to calculate the expression levels of tested genes (18). For the calculations of relative gene expression levels, these normalized data were used. Each test data from independent experiments were repeated at least three times.

\section{Statistical analysis}

Statistical data analysis was performed using the SPSS program (Version 23, SPSS, Chicago, IL, USA). All data are expressed as mean \pm standard error. Student's t-test was used for comparisons between the Lactobacillus spp. metabolites treated and untreated groups. $\mathrm{P}$ values $<0.05$ were considered significant.

\section{RESULTS}

\section{Anti-QS activity of Lactobacillus sp. metabolites}

The QS inhibitory activity was determined by the presence of transparent inhibition zones around the wells that were filled with the metabolites. All tested metabolites showed anti-QS activity (indicated as A in Figure 1).

Additionally, the supernatants of $P$. aeruginosa cells were treated with the metabolites of Lactobacillus isolates in the biofilm environment which were examined for their anti-QS activity. Anti-QS effects of the metabolites of Lactobacillus isolates and the metabolites obtained after contact with $P$. aeruginosa biofilm cells were determined. Our results showed that there were decreases in the radius of inhibition zones of violacein pigment after exposure to the biofilm cells indicating that the biofilm environment leads to a decrease in the antiQS activities of the Lactobacillus spp. metabolites (indicated as B in Figure 1).

\section{Expression of QS genes in $P$. aeruginosa}

The metabolites of isolates were tested on $P$. aeruginosa biofilms and their effects on the expression levels of genes encoding QS signal molecules that were responsible for the communications between the cells in biofilms were determined. The mRNA expression results of tested genes in $P$. aeruginosa were shown in Figure 2. Compared with the nontreated biofilm cells, mRNA levels of $r h l R$, lasR, lasl and mvf were significantly down-regulated in all treated biofilm cells of $P$. aeruginosa $(\mathrm{p}<0.05)$.

Table 1. Primers used in this study

\begin{tabular}{ccc}
\hline Genes & \multicolumn{1}{c}{ Forward } & Reverse \\
\hline$m v f$ & AACCTGGAAATCGACCTGTG & AACCTGGAAATCGACCTGTG \\
$l a s R$ & ACGCTCAAGTGGAAAATTGG & GTAGATGGACGGTTCCCAGA \\
$l a s l$ & CTACAGCCTGCAGAACGACA & ATCTGGGTCTTGGCATTGAG \\
$r h l R$ & AGGAATGACGGAGGCTTTTT & CCCGTAGTTCTGCATCTGGT \\
proc $^{*}$ & GGCGTATTTCTTCCTGCTGA & CCTGCTCCACTAGTGCTTCG \\
\hline
\end{tabular}

*Housekeeping gene. 

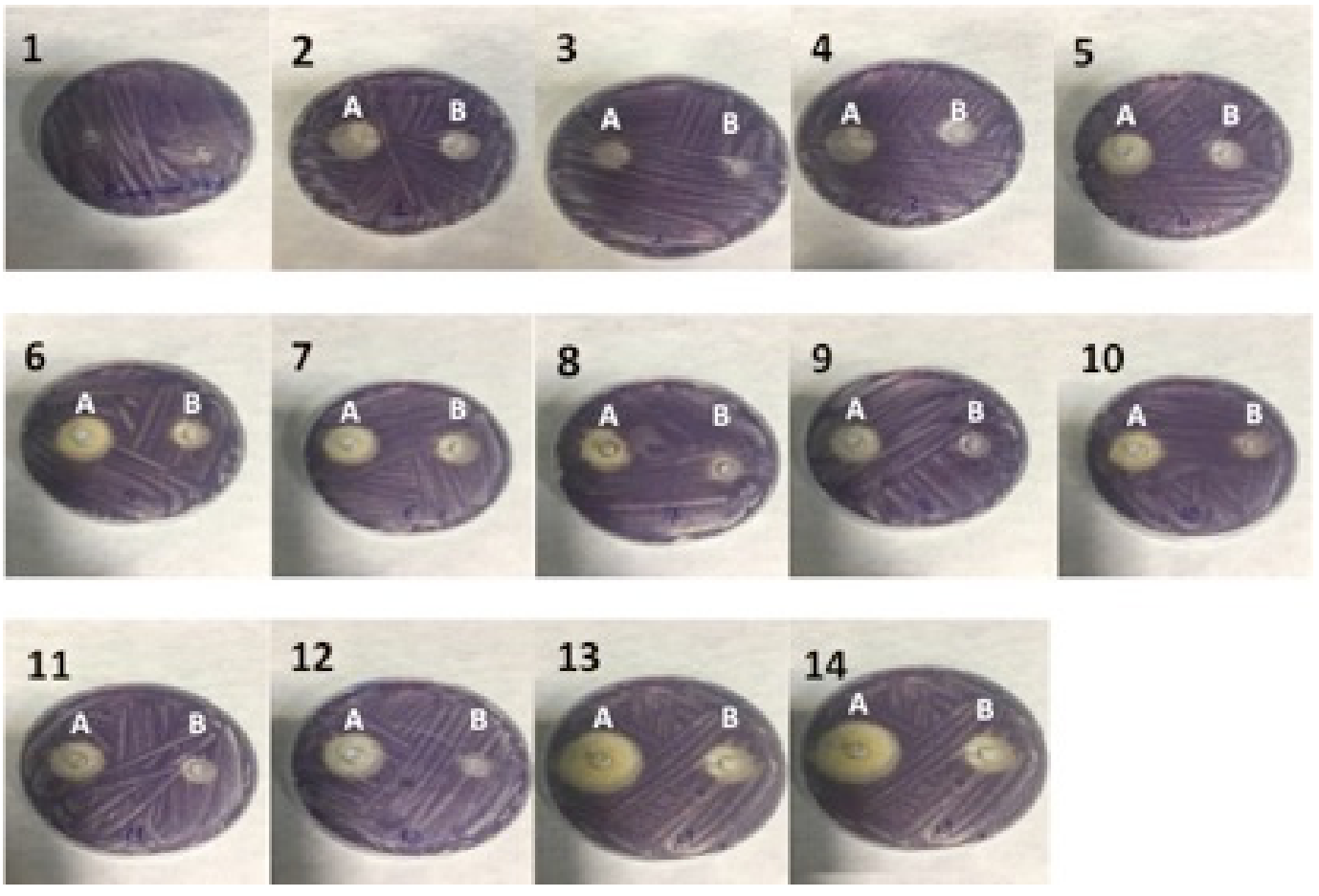

Figure 1. (A) QS inhibitory activity of the metabolites of Lactobacillus isolates (B) QS inhibitory activity of the $P$. aeruginosa biofilm supernatants treated with the metabolites of Lactobacillus isolates 1: MRS broth as negative control 2: $L$. helveticus 1; 3: L. fermantum 1; 4: L. jensenii 1; 5: L. gasseri 1; 6: L. gasseri 2; 7: L. gasseri 3; 8: L. gasseri 4; 9: L. gasseri 5; 10 : L. vajinalis $1 ; 11$ : L. crispatus $1 ; 12$ : L. vajinalis $2 ; 13$ : L. crispatus $2 ; 14$ : L. gasseri 6.

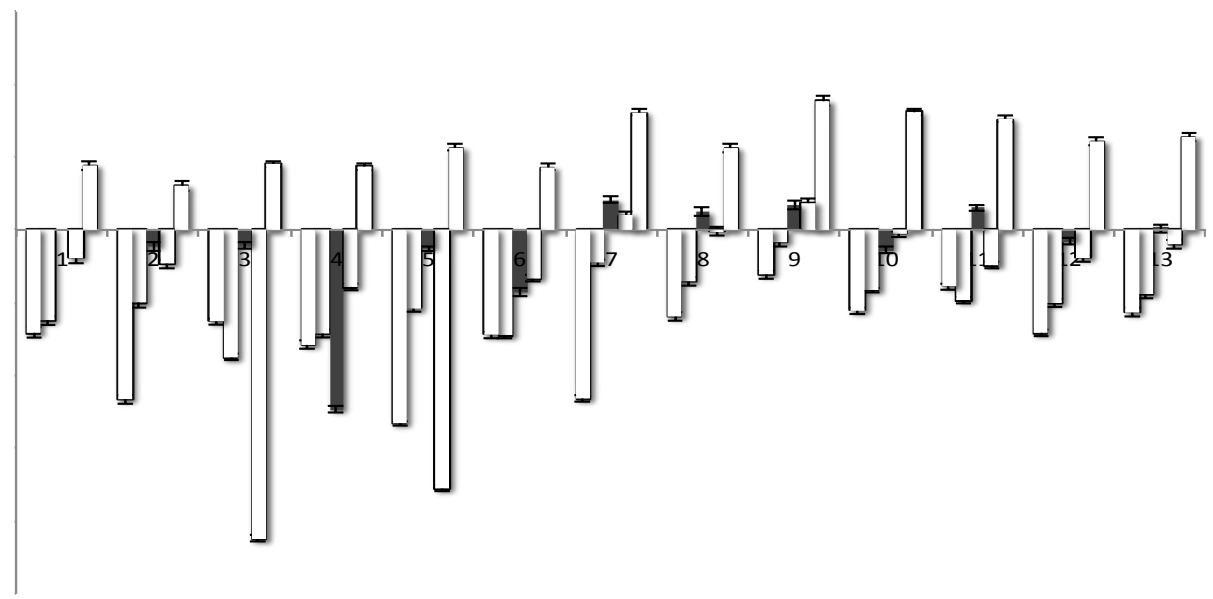

Figure 2. Relative expression results of QS-related genes of P.aeruginosa PA01. $\mathrm{P}<0.05$ was considered statistically significant. 1: L.helveticus 1; 2: L. fermantum 1; 3: L. jensenii 1; 4: L. gasseri 1; 5: L. gasseri 2; 6: L. gasseri 3; 7 : L. gasseri 4; 8: L. gasseri 5; 9: L. vajinalis $1 ; 10$ : L. crispatus $1 ; 11$ : L. vajinalis $2 ; 12$ : L. crispatus $2 ; 13:$ L. gasseri 6. 


\section{DISCUSSION}

P. aeruginosa is one of the pathogens leading to chronic and persistent infections, usually caused by biofilms controlled by QS system (19). Current chemical agents are inadequate for the eradication of biofilms, hence new strategies that can be effective are needed. Results from several studies suggest that targeting the QS system in $P$. aeruginosa may be a new strategy to struggle against biofilmrelated $P$. aeruginosa infections $(20,21)$. Activation of the QS system may lead to increases in virulence of pathogens such as $P$. aeruginosa and agents particularly inhibiting this system are called antiQS inhibitors (22). The present study is particularly important in terms of investigating the anti-QS activity of bacterial metabolites of vaginal flora member Lactobacillus sp. which have attracted the attention of researchers in recent years. Our results show that suppression of QS-mediated violacein production of $\mathrm{C}$. violaceum, when threated with the metabolites of 13 different Lactobacillus isolates, is a preliminary indicator that these strains have anti-QS property. The inhibition zones of violacein around the wells separately filled with both the metabolites of Lactobacillus isolates only and with the metabolites obtained after contact with $P$. aeruginosa biofilm cells were determined as anti-QS activity in both conditions. Our results suggest that the interaction with $P$. aeruginosa biofilm cells leads to decreases in the anti-QS activity of the isolates by a yet unknown mechanism.

In a study, antibiofilm effects of $L$. pentosus and $L$. plantarum metabolites isolated from fermented dairy products on $P$. aeruginosa and Bacillus cereus biofilms were reported (23). In another study, $L$. rhamnosus EMCC 1105 and L. gasseri EMCC 1930 strains were reported to be effective against $P$. aeruginosa, Escherichia coli, and S. aureus biofilms (24). Melo et al. showed that the metabolites of $L$. fermentum TCUESC01 and L. plantarum TCUESCO2 which were isolated from cocoa fermentation had antibiofilm effect on the biofilm of a resistant S. aureus CCMB 262 strain (13). In the study of Shokri et al., different metabolites such as lactic acid, acetic acid and formic acid produced by $L$. fermentum isolates showed an anti-biofilm effect on $80 P$. aeruginosa isolates with multi-drug resistance. The usage of $L$. fermentum isolates as possible therapeutic agents in the control of resistant strains of $P$. aeruginosa has also been proposed in the same study (14).

Gene expression analysis results of anti-biofilmspecific agents have shown that they inhibit biofilm formation by causing a decrease in the expression of QS-related genes (17). The majority of virulence factors such as lasA-elastase, lasA-staphylolytic protease, toxA-exotoxin $\mathrm{A}$, and aprA-alkaline protease produced by $P$. aeruginosa are synthesized through the rhl quorum sensing system that plays an important role in the irreversible attachment phase of the biofilm and the las system which positively controls the rhl system (25). In our study, we determined the transcription levels of QS-related genes such as lasR/I, rhlR/I and mvfR in order to evaluate the possible relationship between the inhibitory effect of Lactobacillus supernatants and the QS system. Significant reductions in mRNA levels of lasR/I, rhlR/I and mvfR genes were obtained for all tested Lactobacillus supernatants, which explains the anti-biofilm effect of these strains on $P$. aeruginosa biofilms that were observed in our previous study (12).

Soheili et al. have determined the effect of natural antimicrobial compound 3-Phenyllactic acid (PLA) produced by Lactobacillus spp. on biofilm formed by P. aeruginosa PAO1 and on QS system by using in vitro and in silico analysis. The results of the study showed that pyocyanin, hemolysin, protease, rhamnolipid and swarming activity were decreased and Rhl and Pqs related QS system was suppressed in the biofilm cells treated with PLA (26). Li et al. showed the bacteriocin-mediated antimicrobial effect of $L$. plantarum AB-1 and $L$. casei strains on 
Shewanella baltica, the specific spoilage organism of the refrigerated shrimp. It was also concluded in the study that this antimicrobial effect was regulated by the Al-2 / LuxS-mediated QS system (27).

\section{CONCLUSION}

Many virulence genes may be overexpressed through the QS system in microorganisms following the transformation into more pathogenic forms. The discovery of new antimicrobial compounds targeting the QS system will result in inhibition of bacterial communication, thereby showing its activity without selective pressure on microorganisms. In our study, the metabolites of Lactobacillus vaginal isolates have been shown to have anti-QS activity. These natural compounds, alone or in combination with antibiotics, maybe future candidates for the treatment of $P$. aeruginosa biofilms in clinics.

\section{REFERENCES}

1. Gomez MI, Prince A. Opportunistic infections in lung disease: Pseudomonas infections in cystic fibrosis. Curr Opin Pharmacol, 2007; 7(3): 244-51. doi:10.1016/j.coph.2006.12.005. 2007.

2. Fuqua WC, Winans SC, Greenberg EP. Quorum Sensing in Bacteria - the Luxr-Luxi Family of Cell Density-Responsive Transcriptional Regulators. J Bacteriol, 1994; 176(2): 269-75.

3. Rajkumari J, Borkotoky S, Reddy D, Mohanty SK, Kumavath R, Murali A, et al. Anti-quorum sensing and anti-biofilm activity of 5-hydroxymethylfurfural against Pseudomonas aeruginosa PA01: Insights from in vitro, in vivo and in silico studies. Microbiol Res, 2019; 226: 19-26. doi:10.1016/j. micres.2019.05.001.

4. Pearson JP, Gray KM, Passador L, Tucker KD, Eberhard A, Iglewski BH, et al. Structure of the Autoinducer Required for Expression of Pseudomonas-Aeruginosa Virulence Genes. P Natl Acad Sci USA, 1994; 91(1): 197-201. doi: 10.1073/ pnas.91.1.197.

5. Sankar Ganesh P, Ravishankar Rai V. Attenuation of quorum-sensing-dependent virulence factors and biofilm formation by medicinal plants against antibiotic resistant Pseudomonas aeruginosa. J Tradit Complement Med, 2018; 8(1): 170-7. doi:10.1016/j.jtcme.2017.05.008.
6. Pearson JP, Passador L, Iglewski BH, Greenberg EP. A second $\mathrm{N}$-acylhomoserine lactone signal produced by Pseudomonas aeruginosa. Proc Natl Acad Sci USA, 1995; 92(5): 1490-4. doi:10.1073/pnas.92.5.1490.

7. Pearson JP, Pesci EC, Iglewski BH. Roles of Pseudomonas aeruginosa las and rhl quorum-sensing systems in control of elastase and rhamnolipid biosynthesis genes. J Bacteriol, 1997; 179(18): 5756-67. doi:10.1128/jb.179.18.5756-5767.1997.

8. Sawa T, Ohara M, Kurahashi K, Twining SS, Frank DW, Doroques DB, et al. In vitro cellular toxicity predicts Pseudomonas aeruginosa virulence in lung infections. Infect Immun, 1998; 66(7): 3242-9.

9. Shukla V, Bhathena Z. Broad Spectrum Anti-Quorum Sensing Activity of Tannin-Rich Crude Extracts of Indian Medicinal Plants. Scientifica, 2016. doi:582 301310.1155/2016/5823013.

10. Davoodabadi A, Dallal MMS, Lashani E, Ebrahimi MT. Antimicrobial Activity of Lactobacillus spp. Isolated From Fecal Flora of Healthy Breast-Fed Infants Against Diarrheagenic Escherichia coli. Jundishapur J Microb, 2015; 8(12). doi: e2785210.5812/ jjm. 27852 . 
11. Eryilmaz M, Gurpinar SS, Palabiyik IM, Guriz H, Gerceker D. Molecular Identification and Antimicrobial Activity of Vaginal Lactobacillus sp. Curr Pharm Biotechno, 2018; 19(15): 1241-7. doi:10 $.2174 / 1389201020666190110164123$.

12. Eryılmaz M, Kart D, Gürpınar SS. Investigation of Antibiofilm Activities of Lactobacillus sp. Metabolites Isolated from Vaginal Flora. Journal of Turkish Society of Microbiology, 2019; 49(3): 16974.

13. Melo TA, dos Santos TF, de Almeida ME, Fontes LAG, Andrade EF, Rezende RP, et al. Inhibition of Staphylococcus aureus biofilm by Lactobacillus isolated from fine cocoa. BMC Microbiol, 2016. doi:25010.1186/s12866-016-0871-8.

14. Shokri D, Khorasgani MR, Mohkam M, Fatemi SM, Ghasemi Y, Taheri-Kafrani A. The Inhibition Effect of Lactobacilli Against Growth and Biofilm Formation of Pseudomonas aeruginosa. Probiotics Antimicro, 2018; 10(1): 34-42. doi:10.1007/s12602-017-92679.

15. Stoyancheva G, Marzotto M, Dellaglio F, Torriani $S$. Bacteriocin production and gene sequencing analysis from vaginal Lactobacillus strains. Arch Microbiol, 2014; 196: 645-53.

16. Kart D, Tavernier S, Van Acker $\mathrm{H}$, Nelis HJ, Coenye T. Activity of disinfectants against multispecies biofilms formed by Staphylococcus aureus, Candida albicans and Pseudomonas aeruginosa. Biofouling, 2014; 30(3): 377-83. doi:10.1080/08927014.2013.8 78333.

17. Qu L, She PF, Wang YX, Liu FX, Zhang D, Chen LH, et al. Effects of norspermidine on Pseudomonas aeruginosa biofilm formation and eradication. Microbiologyopen, 2016; 5(3): 402-12. doi:10.1002/ mbo3.338.

18. Livak KJ, Schmittgen TD. Analysis of relative gene expression data using real-time quantitative PCR and the 2(T)(-Delta Delta C) method. Methods.,2001; 25(4): 402-8. doi:10.1006/meth.2001.1262.

19. Sharma G, Rao S, Bansal A, Dang S, Gupta S, Gabrani R. Pseudomonas aeruginosa biofilm: Potential therapeutic targets. Biologicals, 2014; 42(1): 1-7. doi:10.1016/j.biologicals.2013.11.001.
20. Brackman G, Hillaert U, Van Calenbergh S, Nelis $\mathrm{HJ}$, Coenye T. Use of quorum sensing inhibitors to interfere with biofilm formation and development in Burkholderia multivorans and Burkholderia cenocepacia. Res Microbiol, 2009; 160(2): 144-51. doi:10.1016/j.resmic.2008.12.003.

21. Musk DJ, Hergenrother PJ. Chemical countermeasures for the control of bacterial biofilms: Effective compounds and promising targets. Curr Med Chem, 2006; 13(18): 2163-77. doi:10.2174/092986706777935212.

22. Abraham SVPI, Palani A, Ramaswamy BR, Shunmugiah KP, Arumugam VR. Antiquorum Sensing and Antibiofilm Potential of Capparis spinosa. Arch Med Res, 2011; 42(8): 658-8. doi:10.1016/j. arcmed.2011.12.002.

23. Khiralla GM, Mohamed EAH, Farag AG, Elhariry $H$. Antibiofilm effect of Lactobacillus pentosus and Lactobacillus plantarum cell-free supernatants against some bacterial pathogens. J Biotech Res, 2015; 6: 86-95.

24. Ganchev I. Antibiofilm activity of Lactobacillus strains. Sci J Chem, 2018; 6(5):77-82. doi. org:10.11648/j.sjc. 20180605.11 .

25. Hentzer M, Riedel K, Rasmussen TB, Heydorn A, Andersen JB, Parsek MR et al. Inhibition of quorum sensing in Pseudomonas aeruginosa biofilm bacteria by a halogenated furanone compound. MicrobiolSgm, 2002; 148: 87-102. doi:10.1099/00221287148-1-87.

26. Soheili V, Tajani AS, Ghodsi R, Bazzaz BSF. AntiPqsR compounds as next-generation antibacterial agents against Pseudomonas aeruginosa: A review. Eur J Med Chem, 2019; 172: 26-35. doi:10.1016/j. ejmech.2019.03.049.

27. Li JP, Yang XY, Shi GC, Chang J, Liu ZY, Zeng MY. Cooperation of lactic acid bacteria regulated by the Al-2/LuxS system involve in the biopreservation of refrigerated shrimp. Food Res Int, 2019; 120:67987. doi:10.1016/j.foodres.2018.11.025. 